Volume. 3 Nomor. 2

Periode: Juli - Desember 2019; hal. 55-63

p-ISSN : 2580-1112; e-ISSN : 2655-6669

Copyrighr @2019

Penulis memiliki hak cipta atas artikel ini

journal homepage: https://ejournal.akperfatmawati.ac.id

Jurnal Ilmiah Keperawatan Orthopedi

(JIKO)

\title{
Peningkatan Perilaku Perawatan Klien Tb Paru Melalui Pendidikan Kesehatan
}

\author{
Ani Nuraeni ${ }^{1}$, Nailah Amalia ${ }^{2}$ \\ Akademi Keperawatan Fatmawati, Jakarta
}

\begin{abstract}
Abstrak
Tuberkulosis paru (TB Paru) merupakan penyakit infeksius kronik dan berulang yang biasanya mengenai paru disebabkan oleh Mycobacterium Tuberculosis. Penyakit ini ditularkan melalui udara yang terkontaminasi droplet penderita ketika batuk, bersin, bicara, atau bernyanyi. Penularan dapat terjadi pada anggota keluarga yang lain apabila pasien TB Paru tidak melakukan perawatan seperti pengobatan TB Paru secara tuntas, memakai masker, melakukan etika batuk, mengkonsumsi makanan bergizi, serta memodifikasi lingkungan. Salah satu upaya untuk mengurangi penularan penyakit TB Paru perlu meningkatkan perilaku pencegahan dan penularan TB Paru bagi klien dan keluarganya melalui pendidikan kesehatan. Studi kasus ini bertujuan untuk mengidentifikasi peningkatan perilaku perawatan TB Paru setelah diberikan pendidikan kesehatan. Rancangan studi kasus menggunakan model deskriptif dan proses keperawatan sebagai pendekatan. Pengumpulan data menggunakan metode wawancara dan kuesioner pada dua orang subjek yang telah terdiagnosa TB Paru.Hasil studi kasus menunjukkan adanya peningkatan perilaku perawatan setelah diberikan pendidikan kesehatan selama 5 hari. Studi kasus ini merekomendasikan perlunya program pendidikan kesehatan secara terjadwal bagi klien dan keluarga baik dilakukan di Puskesmas maupun kunjungan rumah.
\end{abstract}

Kata Kunci: Tuberkulosis Paru, Pendidikan Kesehatan, Perilaku Perawatan

\begin{abstract}
Pulmonary tuberculosis (pulmonary TB) is a chronic and recurrent infectious disease that is usually occurs to the lungs by Mycobacterium Tuberculosis. This disease is transmitted through air contaminated with droplets of patients coughing, sneezing, talking even singing. Transmission can be carried out to the family members who are TB delayed or uncompleted therapy, not pay intention the important of wear masks, improper cough ethics, consume nutritious food, and improve the environment. The preference to reduce transmission of pulmonary $T B$ disease is health education of prevention transmit pulmonary $T B$ to clients and assistance. This case study discusses about improving of family behavior of prevent of spreading pulmonary $T B$ after given health education. The design of the case study used descriptive models and nursing processes as approaches. Data collection using interview methods and questionnaires on two subjects and families who have been diagnosed with pulmonary TB. The results of the study showed an increasing in care policies after being given health education for 5 days. This case study
\end{abstract}

1,2 e-mail: aninauradaifa@gmail.com 
discusses the need for a health education program scheduled for clients and families both at the Puskesmas and home visits.

Keywords: Pulmonary Tuberculosis, Health of Education And Behavioral Cares

\section{Pendahuluan}

Tuberkulosis paru merupakan penyakit infeksius kronik dan berulang yang biasanya mengenai paru dan disebabkan oleh Mycobacterium Tuberculosis. Penyakit ini dapat ditularkan melalui droplet yang ditularkan melalui udara dihasilkan ketika orang terinfeksi batuk, bersin, bicara, atau bernyanyi. Infeksi dapat terjadi ketika pejamu yang rentan bernapas di udara yang mengandung droplet nuklei dan partikel terkontaminasi menghindari pertahanan normal saluran napas atas untuk mencapai alveoli.

Tanda dan gejala TB Paru yaitu batuk berdahak lebih dari 3 minggu disertai dengan batuk berdarah, nyeri dada, berkeringat pada malam hari, penurunan berat badan, demam pada waktu siang atau sore hari, kelelahan, kehilangan nafsu makan, dan sesak napas. Namun, dari tanda dan gejala TB Paru jika tidak diatasi dengan benar maka akan menimbulkan komplikasi penyakit TB Paru seperti pleuritis, efusi pleura, laringitis dan TB usus (LeMone, Burke, \& Bauldoff, 2015).

Menurut data WHO tahun 2016 angka prevalensi di dunia diperkirakan terdapat 10,4 juta kasus insiden TB yang setara dengan 120 kasus per 100.000 penduduk. Adapun 5 negara dengan insiden kasus tertinggi yaitu India, Indonesia, Cina, Philipina dan Pakistan. Sebagian besar prevalensi insiden TB pada tahun 2016 terjadi di kawasan Asia Tenggara $(45 \%)$ dimana Indonesia merupakan salah satu di dalamnya dan 25\% terjadi di kawasan Afrika. Jumlah kasus baru TB di Indonesia sebanyak 420.994 kasus pada tahun 2017 (data per 17 Mei 2018). Berdasarkan Riskesdas prevalensi penderita TB Paru di
Indonesia pada tahun 2007 sebesar 1,0\%. Angka prevalensi ini mengalami penurunan pada tahun 2013 menjadi 0,4\%, kemudian pada tahun 2018 didapatkan hasil prevalensi 0,4 \% penduduk terdiagnosis TB Paru pada kasus dengan batuk lebih dari 2 minggu sebanyak 3,9\% dan kasus dengan batuk berdarah berjumlah 2,8 \% (Kemenkes, 2018).

Adapun angka prevalensi TB Paru di DKI Jakarta pada tahun 2007 berjumlah $0,71 \%$ angka prevalensi ini mengalami penurunan pada tahun 2013 menjadi $0,6 \%$, sedangkan kasus TB Paru dengan gejala batuk lebih dari 2 minggu $4,2 \%$ dan kasus dengan batuk darah sebanyak 1,9 \%. Di Indonesia TB Paru merupakan penyebab kematian nomor tiga setelah penyakit jantung dan saluran pernapasan pada semua kelompok umur serta nomor satu untuk golongan penyakit infeksi. Korban meninggal akibat TB paru di Indonesia sebanyak 61.000 kematian tiap tahunnya (Kemenkes, 2013).Berdasarkan laporan kunjungan pasien yang berobat ke Poli TB Puskesmas Kecamatan Pancoran pada tahun 2017 didapatkan data 167 pasien, dan pada tahun 2018 didapatkan peningkatan data pengunjung pasien di Poli TB Paru menjadi 202 pasien.

Keluarga merupakan unit terkecil dari masyarakat yang terdiri dari kepala keluarga, dan beberapa orang yang berkumpul serta tinggal di suatu tempat di bawah satu atap dalam keadaan saling bergantung (Ali, 2009). Apabila terdapat anggota keluarga yang menderita TB Paru maka dapat menyebabkan penularan pada anggota keluarga yang lainapabila penderita tidak melakukan perawatan dengan benar seperti tidak memakai masker, tidak melakukan etika batuk, 
tidak mengkonsumsi makanan bergizi, tidak tuntas minum obat, dan lain-lain.

Mengingat perilaku perawatan yang kurang baik akan berdampak terjadinya penularan kepada anggota keluarga lain maka perlu dilakukan upaya perubahan perilaku pada klien. Menurut Setiawati dan Dermawan (2008), yang menyatakan bahwa perilaku dapat berubah melalui pemberian informasi tentang sesuatu hal yang dapat merubah perilaku seseorang. Perilaku perawatan TB Paru yang kurang baik dapat diubah melalui pemberian informasi dengan menggunakan strategi pendidikan kesehatan.

Pendidikan kesehatan merupakan serangkaian upaya yang ditujukan untuk mempengaruhi orang lain, mulai dari individu, kelompok, keluarga dan masyarakat agar terlaksananya perilaku hidup sehat. Pendidikan kesehatan bukan hanya kegiatan penyadaran masyarakat atau pemberian dan peningkatan pengetahuan masyarakat tentang kesehatan tetapi juga merupakan upayaupaya dalam memfasilitasi perubahan perilaku kesehatan yang diinginkan.

Pendidikan kesehatan dituntut bukan hanya melakukan perubahan terhadap perilaku saja melainkan juga upaya perubahan lingkungan, sosial, budaya, politik dan ekonomi. Dengan demikian, pendidikan kesehatan memiliki program-program kesehatan yang dirancang untuk membawa perubahan baik dalam masyarakat sendiri maupun organisasi dan lingkungannya (Setiawati \& Dermawan, 2008). Pendidikan kesehatan sangat penting bagi klien dan keluarga karena keluarga yang akan merawat klien di rumah dan keluarga yang selalu memberikan dukungan untuk klien.

Hasil penelitian Pratama, Widodo dan Listyorini (2013), menyatakan bahwa terdapat perubahan perilaku klien setelah diberikan pendidikan kesehatan. Hal ini sesuai dengan penelitian Infanti (2011) yang memperoleh hasil $85.2 \%$ tindakan pencegahan dan penularan penyakit yang dilakukan penderita TB Paru dalam kategori baik. Hasil uji statistik menunjukkan terdapat pengaruh pendidikan kesehatan yang bermakna terhadap tindakan penderita TB Paru tentang pencegahan dan penularan TB Paru.

Kondisi ini menunjukkan bahwa pengetahuan yang semakin baik dapat mempengaruhi perilaku menjadi lebih baik. Perilaku yang baik ini kemudian diimplementasikan dalam berperilaku hidup bersih dan sehat secara baik. Oleh karena itu keluarga sangat penting dalam membantu dan merawat klien dengan TB Paru, karena keluarga berperan dalam pendidik, pelindung dan pemberi rasa aman kepada anggota keluarga.

Berdasarkan hal tersebut maka diperlukan program pendidikan kesehatan pada klien dan keluarga. Keluarga juga menjadi perantara yang cukup efektif dan efisien untuk berbagai usaha kesehatan masyarakat. Kesehatan masyarakat dapat ditingkatkan terutama melalui peningkatan kesehatan keluarga.

Pada perawatan kesehatan keluarga ini juga berfokus pada peningkatan perawatan diri (self care), pendidikan kesehatan, dan konseling keluarga serta upaya keperawatan yang dapat mengurangi risiko akibat pola hidup dan bahaya dari lingkungan. Upaya tersebut bertujuan untuk meningkatkan derajat kesehatan keluarga bagi setiap anggota keluarga (Zaidin, 2009). Berdasarkan uraian di atas, penulis tertarik untuk melakukan pelaksanaan pendidikan kesehatan untuk meningkatkan perilaku perawatan pada klien TB Paru di Puskesmas Kecamatan Pancoran Jakarta Selatan.

\section{Metode}

Jenis rancangan penelitian ini adalah studi kasus deskriptif yang bertujuan mengidentifikasi peningkatan perilaku perawatan klien dengan TB Paru setelah diberikan pendidikan kesehatan. Subjek penelitian ini terdiri dari 2 
keluarga yang memiliki anggota keluarga dengan masalah kesehatan TB Paru.

Pemilihan keluarga yang menjadi subjek penelitian adalah klien yang berobat ke Puskesmas Kecamatan Pancoran yang memenuhi kriteria yaitu telah terdiagnosa TB Paru oleh tenaga kesehatan, tinggal di wilayah Kecamatan Pancoran, mampu berkomunikasi dengan baik dan kooperatif serta bersedia untuk menjadi subjek penelitian.

Setelah subjek menyetujui untuk berpartisipasi dalam penelitian selanjutnya peneliti melakukan kunjungan rumah untuk melakukan pendidikan kesehatan pada keluarga. Peneliti melakukan pendidikan kesehatan sebanyak 3 kali pertemuan. Pada pertemuan pertama penulis memberikan pendidikan kesehatan tentang penyakit TB Paru yang dilakukan selama 30 menit dan memberikan kuesioner pre test perilaku perawatan TB Paru. Pertemuan kedua memberikan pendidikan kesehatan tentang pencegahan dan perawatan TB Paru selama 30 menit. Lalu pertemuan ketiga memberikan pendidikan kesehatan tentang modifikasi lingkungan yang sehat bagi klien TB Paru dan manfaat pelayanan kesehatan yang dilakukan selama 30 menit.Kemudian peneliti kembali mengunjungi rumah subjek tiga hari setelah pemberian pendidikan kesehatan untuk mengisi kuesioner post test perilaku perawatan TB Paru.

\section{Hasil}

Tabel 1

Karakteristik Demografi Kedua Subjek

\begin{tabular}{clcc}
\hline No. & Karakteristik & Subjek 1 & Subjek 2 \\
\hline 1 & Umur & 43 tahun & 30 tahun \\
\hline 2 & Pendidikan & SD & SMA \\
\hline 3 & Tipe & Keluarga & Single \\
& Keluarga & Inti & Parents \\
\hline
\end{tabular}

Berdasarkan table-1 diketahui bahwa terdapat perbedaan umur, pendidikan dan tipe keluarga pada kedua subjek. Subjek 1 berumur 43 tahun, berpendidikan SD dan memiliki tipe keluarga inti. Sedangkan subjek 2 berumur 30 tahun, berpendidikan SMA dan memiliki tipe keluarga single parents.

Diagram 1

Evaluasi Perilaku Perawatan TB Paru

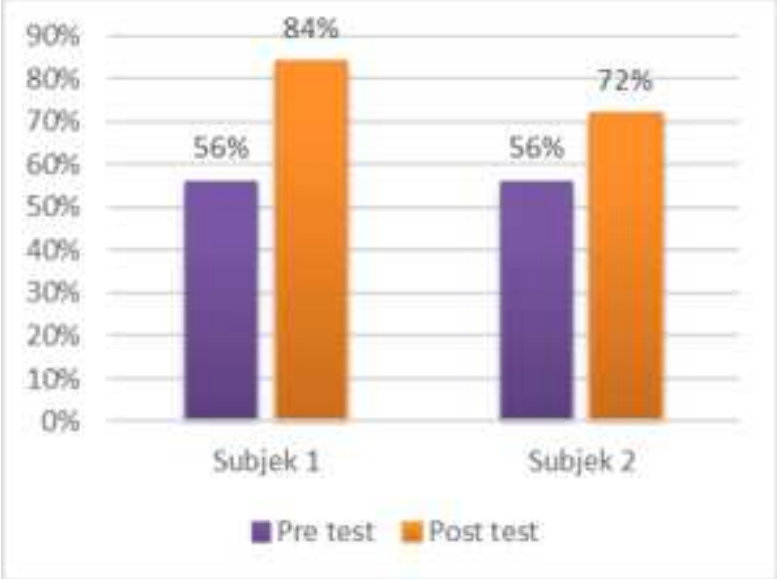

Berdasarkan diagram-1 diketahui terdapat perbedaan peningkatan perilaku perawatan TB Paru pada kedua subjek setelah diberikan pendidikan kesehatan. Peningkatan perilaku perawatan TB Paru subjek 1 lebih tinggi dibandingkan dengan subjek 2 dibuktikan dengan sebelum dilakukan pendidikan kesehatan subjek 1mendapatkan nilai $56 \%$ dengan kategori cukup, dan setelah diberikan pendidikan kesehatan terjadi peningkatan perilaku menjadi $84 \%$ dengan kategori baik. Sedangkan pada subjek 2 sebelum dilakukan pendidikan kesehatan mendapatkan nilai 56\% dengan kategori cukup dan setelah diberikan pendidikan kesehatan menjadi $72 \%$ dengan kategori cukup.

\section{Pembahasan \\ Umur}

Hasil penelitian didapatkan faktor umur menyebabkan perbedaan peningkatan perilaku perawatan TB Paru dibuktikan dengan subjek 1 berumur 43 tahun menunjukkan peningkatan perilaku lebih tinggi dibandingkan dengan subjek 2 yang berumur 30 tahun. Pernyataan ini sesuai dengan penelitian Bagoes, Priyadi, dan Edi (2006) bahwa perubahan perilaku dapat disebabkan karena proses pendewasaan (maturation). 
Melalui pengalaman umur, individu, yang bersangkutan telah melakukan adaptasi perilaku terhadap lingkungan. Pernyataan ini menunjukkan bahwa dengan umur responden yang semakin dewasa memudahkan subjek untuk beradaptasi dengan lingkungan yang ada di sekitarnya.

Hasil penelitian Erawatyaningsih, Purwanto, dan Subekti (2009) menjelaskan responden kelompok umur 45 - 59 tahun menunjukkan tidak patuh 2.48 kali dibanding kelompok umur lainnya.Berdasarkan penelitian tersebut menyatakanfaktor umur bukan merupakan faktor penentu ketidakpatuhan penderita dalam pengobatan karena responden berusia muda maupun usia lanjut memiliki motivasi untuk hidup sehat dan selalu memperhatikan kesehatannya.

Beberapa penelitian lain telah mengkonfirmasi bahwa tidak ada hubungan yang bermakna antara umur dengan kepatuhan berobat. Umur tidak berpengaruh terhadap tindakan seseorang karena adanya faktor perantara seperti sikap seseorang dan faktor lain yang mempengaruhi kehendal seseorang.

\section{Pendidikan}

Hasil penelitian didapatkan tidak ada hubungan antara pendidikan dengan peningkatan perilaku perawatan TB Paru, dibuktikan dengan pendidikan terakhir subjek 1 yaitu tamat SD dikategorikan dengan perilaku baik setelah diberikan pendidikan kesehatan, sedangkan pendidikan terakhir subjek 2 yaitu tamat SLTA dikategorikan dengan perilaku cukup setelah diberikan pendidikan kesehatan.

Hasil penelitianini sesuai dengan Maulidya, Redjeki, dan Fanani (2017) yang menyatakan bahwa tidak ada hubungan antara pendidikan dengan perilaku perawatan TB Paru.

Menurut Maulidya, Redjeki, dan Fanani (2017), mayoritas responden menganggap bahwa penyakit TB Paru merupakan penyakit yang berbahaya dan menakutkan, sehingga baik responden yang bersekolah hanya lulus SD maupun yang berpendidikan hingga lulus SMA atau perguruan tinggi, mereka merasa terdorong untuk memeriksakan diri ke fasilitas pelayanan kesehatan dan menjalani pengobatan selama $6-8$ bulan.

Oleh sebab itu, pada dasarnya tingkat pendidikan seseorang tidak berpengaruh secara langsung terhadap perawatan keberhasilan pengobatan TB Paru. Menurut penelitian Hakim dan Putri (2015), menjelaskan bahwa latar belakang pendidikan tidak berpengaruh terhadap perawatan TB Paru. Pasien dengan pendidikan rendah dan pendidikan tinggi mempunyai kecenderungan yang samadalam keteraturan pengobatan.

\section{Tipe Keluarga}

Tipe keluarga inti menurut Sussman (1974) dan Macklin (1988) dalam Friedman, Bowden, dan Jones (2010) yaitu keluarga yang terdiri dari ayah, ibu dan anak sedangkan single parentadalah keluarga yang terdiri salah satu orang tua tinggal bersama anakanaknya. Kaakinen dan Duff (2010) menjelaskan bahwa masing-masing tipe keluarga memiliki kekuatan dan keterbatasan, baik secara langsung atau tidak langsung mempengaruhi terhadap kesehatan individu dan keluarga.

Melalui struktur dan tipe keluarga dapat diidentifikasi efektifitas strategi koping keluarga untuk setiap gangguan atau tuntutan hidup, krisis perawatan kesehatan, peningkatan kesejahteraan dan pencegahan penyakit (Denham, 2005; dalam Kaakinen \& Duff, 2010).

Salah satu strategi koping keluarga adalah strategi dukungan keluarga yang merupakan salah satu faktor yang mempengaruhi kepatuhan dalam pengobatan dan perawatan TB Paru, dimana keluarga berfungsi sebagai sistem pendukung bagi anggota keluarga yang sakit. Dukungan dari keluarga membuat penderita tidak merasa 
terbebani dengan penyakitnya karena adanya perhatian dari keluarga sehingga tidak merasa sendiri (Irnawati, Siagian, \& Ottay, 2016).

Teori tersebut sesuai dengan hasil penelitian ini yang menyatakan bahwa Subjek 1 merupakan tipe keluarga inti, subjek mendapatkan dukungan yang kuat dari suami dan anak-anaknya dalam peningkatan perilaku perawatan TB Paru dengan cara mengingatkan untuk selalu minum obat yang rutin, memotivasi untuk kesembuhan. Sedangkan Subjek 2 merupakan tipe keluarga single parent kurang mendapatkan dukungan, dikarenakan suami subjek 2 sudah meninggal.

Hasil ini sesuai dengan penelitian Maulidya, Redjeki, dan Fanani (2017) bahwa ada hubungan antara adanya dukungan keluarga sebagai pengawas minum obat dengan keberhasilan klien dalam menjalani pengobatan TB Paru.

Dapat disimpulkan bahwa pasien yang memiliki dukungan pengawas minum obat cenderung lebih teratur dalam minum obat dan patuh dalam menjalani pengobatan. Dalam hal ini peran pengawas minum obat yang dapat menjalankan tugasnya dengan baik dan sangat berpengaruh dalam keberhasilan pengobatan TB Paru.

Dukungan keluarga biasanya diterima dari lingkungan sosial yaitu orang-orang yang dekat dengan penderita, termasuk didalamnya adalah anggota keluarga, orang tua, masyarakat dan teman. Faktor dukungan keluarga memiliki hubungan signifikan terhadap perilaku perawatan kesehatan pada penderita TB Paru disebabkan oleh adanya pengawas minum obat dari anggota keluarga.

Menurut penelitian Saifullah, Mulyadi, dan Asniar (2018), mengatakan bahwa dukungan keluarga menunjukkan adanya hubungan dengan kepatuhan minum obat pasien $\mathrm{TB}$ dimana dia menyatakan pengawas minum obat sebaiknya adalah anggota keluarga sendiri yaitu anak atau pasangannya dengan alasan lebih bisa dipercaya. Dari hasil penelitian dapat disimpulkan bahwa dukungan keluarga sangat dibutuhkan oleh klien TB Paru dalam meningkatkan perilaku perawatan pada TB Paru.

\section{Perilaku Perawatan TB Paru}

Hasil penelitian menunjukkan bahwa pendidikan kesehatan sangat berpengaruh dengan peningkatan perilaku perawatan pada TB Paru, didapatkan hasil perilaku perawatan subjek 1 sebelum dilakukan pendidikan kesehatan sebesar nilai $56 \%$ dengan kategori cukup, dan setelah diberikan pendidikan kesehatan terjadi peningkatan perilaku menjadi $84 \%$, sehingga terdapat peningkatan sebanyak $28 \%$.

Perilaku perawatan subjek 2 sebelum dilakukan pendidikan kesehatan didapatkan nilai 56\% dengan kategori cukup dan setelah diberikan pendidikan kesehatan terjadi peningkatan perilaku menjadi $72 \%$, sehingga terdapat peningkatan sebanyak $16 \%$.

Hasil studi ini sesuai dengan penelitian Umammi, Muhlisin, dan Nur (2016) yang menyatakan bahwa ada pengaruh pendidikan kesehatan terhadap perubahan perilaku penderita tentang perawatan pencegahan penularan TB Paru.

\begin{tabular}{|c|c|c|}
\hline Menurut & penelitian & Syaripi, \\
\hline Iryenti, & Wantoro & (2016) \\
\hline $\begin{array}{l}\text { enunjukkan } \\
\text { ndidikan }\end{array}$ & bahwa ada & \\
\hline & loran & \\
\hline
\end{tabular}
Berdasarkan hasil penelitian tersebut menunjukkan bahwa pendidikan kesehatan mampu meningkatkan perilaku perawatan dalam upaya pencegahan penularan TB Paru.

Pendidikan kesehatan menjadi salah satu faktor yang mempengaruhi peningkatan perilaku. Pendidikan kesehatan merupakan serangkaian upaya yang ditujukan untuk mempengaruhi orang lain, mulai dari individu, 
kelompok, keluarga dan masyarakat agar terlaksananya perilaku hidup sehat.

Pendidikan kesehatan bukan hanya kegiatan penyadaran masyarakat atau pemberian dan peningkatan pengetahuan masyarakat tentang kesehatan tetapi juga merupakan upaya-upaya dalam memfasilitasi perubahan perilaku kesehatan yang diinginkan. Pendidikan kesehatan dituntut bukan hanya melakukan perubahan terhadap perilaku saja melainkan juga upaya perubahan lingkungan, sosial, budaya, politik dan ekonomi.

Dengan demikian, pendidikan kesehatan memiliki program-program kesehatan yang dirancang untuk membawa perubahan baik dalam masyarakat sendiri maupun organisasi dan lingkungannya (Setiawati \& Dermawan, 2008).

Hasil penelitian menunjukkan adanya hubungan antara pengetahuan dengan peningkatan perilaku tentang perawatan TB Paru. Pengetahuan tentang perawatan TB Paru subjek 1 didapatkan hasil lebih tinggi karena Subjek 1 pernah mengalami sakit TB Paru 10 tahun yang lalu, dan subjek 1 pernah mendapatkan informasi dari petugas kesehatan tentang perawatan TB Paru. Sedangkan pengetahuan tentang perawatan TB Paru pada Subjek 2 dikategorikan masih kurang, karena Subjek 2 baru pertama kali terdiagnosa TB Paru. Tetapi setelah diberikan pendidikan kesehatan terkait pengetahuan tentang TB Paru, pengetahuan klien menjadi meningkat dibuktikan dengan adanya peningkatan perilaku perawatan TB Paru pada kedua subjek.

Hasil penelitian ini sesuai dengan penelitian Sukana, Heryanto dan Supraptini (2003) yang menyatakan terdapat peningkatan pengetahuan tentang pencegahan dan pengobatan TB Paru setelah diberikan penyuluhan kesehatan dan peningkatan pengetahuan ini berpengaruh terhadap ketaatan penderita untuk minum obat.
Penelitian pendukung lainnya adalah penelitian Umammi, Muhlisin, dan Nur (2016) yang menyatakan bahwa ada pengaruh pendidikan kesehatan terhadap peningkatan pengetahuan dan perilaku dalam perawatan dan pencegahan penularan TB Paru. Penelitian Saifullah, Mulyadi, dan Asniar (2018) menyatakan bahwa responden yang memiliki perilaku baik tentang perilaku pencegahan penyakit TB Paru didukung oleh pengetahuan responden yang sebagian besar sudah baik.

Faktor perilaku penderita TB Paru merupakan salah satu penentu keberhasilan pemberantasan TB Paru. Perilaku taat berobat dan taat minum obat secara teratur dan tuntas dapat diperoleh melalui peningkatan pengetahuan tentang pencegahan dan pengobatan TB Paru. Untuk meningkatkan pengetahuan ini perlu dilakukan pemberian informasi (penyuluhan) yang dilakukan oleh tenaga kesehatan kepada setiap penderita dan keluarganya. Halini sesuai dengan teori Setiawati dan Dermawan (2008) menyatakan bahwa perilaku seseorang akan berubah setelah diberikan penguatan berupa informasi-informasi tentang suatu hal yang biasa merubah perilaku seseorang.

\section{Kesimpulan}

1. Pendidikan kesehatan mampu meningkatkan perilaku perawatan dalam upaya pencegahan penularan TB Paru. Hal ini berarti terdapat peningkatan perilaku perawatan dalam upaya pencegahan penularan TB Paru sebelum dan sesudah pemberian pendidikan kesehatan.

2. Faktor umur mempengaruhi peningkatan perilaku karena perubahan perilaku dapat disebabkan karena proses pendewasaan (maturation). Namun faktor umur bukan merupakan faktor penentu kepatuhan penderita dalam pengobatan karena responden berusia 
muda maupun usia lanjut memiliki motivasi untuk hidup sehat dan selalu memperhatikan kesehatannya.

3. Tingkat pendidikan tidak berpengaruh terhadap peningkatan perilaku karena pasien dengan pendidikan rendah dan pendidikan tinggi mempunyai kecenderungan yang sama dalam melakukanperawatan TB Paru.

4. Tipe keluarga mempengaruhi dukungan yang diberikan keluarga kepada klien TB Paru dalam meningkatkan perilaku perawatan TB Paru. Dukungan keluarga dapat diberikan dengan cara menjadi motivator klien untuk kontrol ke fasilitas kesehatan dan sebagai pengawas minum obat. Dukungan biasanya diterima dari lingkungan sosial yaitu orang-orang yang dekat dengan penderita, yaitu anggota keluarga, orang tua, masyarakat dan teman.

\section{Daftar Pustaka}

Agustina, S, \& Wahjuni, C,U. (2017). Pengetahuan dan tindakan pencegahan penularan penyakit tuberkulosis paru pada keluarga kontak serumah. Diunduh dari http://ejournal.umm.ac.id/index.php /keperawatan/article/vi ew/2865.

Ali, Z. (2009). Pengantar keperawatan keluarga. Jakarta: EGC.

Badan Penelitian \&Pengembangan Kesehatan. (2013). Riset kesehatan dasar riskesdas2013. Jakarta: Kemenkes RI. .(2018). Riset kesehatan dasar riskesdas2018. Jakarta: Kemenkes RI.

Erawatyaningsih, E., Purwanto, \& Subekti,H. (2009). Faktor-faktor yang mempengaruhi ketidakpatuhan berobat pada penderita tuberkulosis paru. Diunduh dari http://www. journal.ugm.ac.id

Friedman, M., Bowden, V.R., \&Jones, E.G. (2010). Buku ajar keperawatan keluarga riset, teori, \&praktik. Ed. 5. Jakarta: EGC.

Infanti, T. (2011). Pengaruh pendidikan kesehatan terhadapat pengetahuan, sikap, dan tindakan pencegahan penularan tuberkulosis paru pada keluarga di Kecamatan Sitiung

Kabupaten Dharmasraya tahun 2010. Diunduh dari: http://: repo.unand.ac.id

Irnawati, N.M., Siagian, I.E.T., \& Ottay, R.I. (2016). Pengaruh dukungan keluarga terhadap kepatuhan minum obat pada penderita tuberkulosis di Puskesmas otoboi Kecil Kota Kotamobagu. Jurnal Kedokteran Komunitas dan Tropik: Volume IV Nomor 1 Februari 2016. Diunduh dari http://ejournal.unsrat.ac.id

Kemenkes RI. (2013). Profil Kesehatan Indonesia 2012. Jakarta:

Kementerian Kesehatan RI.

Lailatul, N, Rohmah, S, \& Wicaksana, A,Y. (2015). Upaya keluarga untuk mencegah penularan dalam perawatan anggota keluarga dengan TB Paru. Diunduh dari http://ejournal.umm.ac.id/ind ex.php/keperawatan/article/view/28 65

LeMone, P., Burke, K, M., \& Bauldoff, G. (2015). Buku ajar keperawatan medikal bedah:

Gangguanrespirasi. Jakarta: EGC.

Manalu, H.S.P. (2010). Faktor-faktor yang mempengaruhi kejadian TB Paru dan upaya penanggulangannya. Diunduh dari http://www.jurnal.unsyiah.ac.id/JIK /article/view/12269

Maulidya, Y., Redjeki, E.S., \& Fanani, E. (2017). Faktor yang empengaruhi keberhasilan pengobatan tuberkulosis (TB) paru pada pasien pasca pengobatan di Puskesmas Dinoyo Kota Malang. Diunduh dari http://www.jurnal 
unsyiah.ac.id/JIK/article/view/1226 9

Notoatmodjo, S. (2012). Promosi kesehatan dan perilaku kesehatan. Jakarta: Rineka Cipta.

Pratama, R.K.O., Widodo, A, \& Listyorini, D. (2013). Pengaruh pendidikan kesehatan terhadap perubahan pengetahuan, sikap dan perilaku tentang kebiasaan berperilaku hidup bersih dan sehat siswa SDN 1 Mandang. Diunduh darihttp://ejournal.umm.ac.id/index. $\mathrm{php} /$ keperawatan/article/view/2865

Saifullah, Mulyadi, Asniar. (2018). Faktor-faktor yang berhubungan dengan perilaku perawatan

kesehatan tuberkulosis paru. Diunduh dari http://www.jurnal.unsyiah.ac.id/JIK /article/view/12269

Setiawati, S. \& Dermawan, A. C. (2008). Pendidikan kesehatan. Jakarta: TIM.

Sukana B, Herryanto \& Supraptini. (2003). Pengaruh penyuluhan terhadap pengetahuan penderita TB Paru di Kabupaten Tangerang. Jurnal Ekologi Kesehatan.Vol.2 No.3, Desember 2003: 282 - 289.

Syaripi, A., Suryenti, V, \& Wantoro, G. (2016). Pengaruh pendidikan kesehatan terhadap upaya pencegahan penularan tuberkulosis paru di Wilayah Kerja Puskesmas Muara Kumpeh. Diunduh dari http://www.jurnal.unsyiah.ac.id/JIK /article/view/12269

Umami, Y.H., Muhlisin, A, \& Nur, D.W. (2016). Pengaruh pendidikan kesehatan tentang tuberkulosis terhadap peningkatan pengetahuan dan sikap penderita dalam pencegahan penularan tuberkulosis. Diunduh dari http://www.jurnal. unsyiah.ac.id/JIK/article/view/1226 9

Widjanarko, B., Prabamurti, P.N., \& Wiayat, E. (2006). Pengaruh karakteristik, pengetahuan dan sikap petugas pemegang program tuberculosis paru Puskesmas terhadap penemuan suspek TB Paru di Kabupaten Blora. Diunduh dari http://www.jurnal.unsyiah.ac.id/JIK /article/view/12269

Wulandari, A,A, Nurjazuli, M., \&Adi, S. (2015). Faktor risiko dan potensi penularan tuberkulosis paru di Kabupaten Kendal, Jawa Tengah. Diunduh dari http://ejournal.umm.ac.id/index.php /keperawatan/article/vi ew/2865 